\title{
Farmakoepidemiologi - et fagfelt i stadig utvikling
}

Statistikk fra Reseptregisteret viser at $71 \%$ av befolkningen fikk utlevert minst ett legemiddel på resept i 2019, 78\% av kvinnene og 65\% av mennene (1). I 2019 ble det solgt legemidler til humant bruk for totalt 19,7 milliarder kroner, nesten en tredobling i forhold til kostnadene i 2000. Legemiddelbruk har med andre ord stor betydning for folkehelsen og store økonomiske konsekvenser.

Registerkoblinger har blitt stadig viktigere i studier av legemiddeleffekter. Et fortrinn som Norge og andre nordiske land har, er de mange helseregistrene som kan kobles sammen på individnivå ved hjelp av det unike personnummeret. De nordiske helseregistrene har fått oppmerksomhet internasjonalt. Crump et al. skrev følgende i en lederartikkel i Journal of Epidemiology and Community Health i 2015: "For example, Nordic prescription databases have enabled numerous landmark studies of the health effects, safety and costeffectiveness of medications that are commonly used in the USA" (2).

Det har imidlertid vært mange barrierer for å få tilgang til koblede registerdata. Spesielt har pseudonymiseringsløsningen til Reseptregisteret vanskeliggjort tilgangen. Sommerschild og medforfattere skriver i dette nummeret at Reseptregisteret nå vil bli transformert til et moderne personidentifiserbart legemiddelregister med samme krypteringsløsning som de andre nasjonale helseregistrene, slik som Pasientregisteret, Medisinsk Fødselsregister og andre norske registre. Det er vedtatt at det nye legemiddelregisteret også skal omfatte legemiddelbruk i sykehus og sykehjem, men det er foreløpig ingen konkret tidsplan for dette.

Etablering av Helseanalyseplattformen er et annet tiltak, som skal forenkle tilgangen til helsedata og legge til rette for avanserte analyser på tvers av helseregistre og andre kilder til helseopplysninger. «På Helseanalyseplattformen skal det etableres en dataplattform med kopier av data og dataprodukter fra landets helseregistre, helseundersøkelser og biobanker» (3). Forberedelser for overføring av data til Helseanalyseplattformen er i gang for noen av helseregistrene, blant annet Bivirkningsregisteret og Kreftregisteret. Reseptregisteret må transformeres til det nye personidentifiserbare legemiddelregisteret før data kan overføres til plattformen. Saksbehandlingen av søknader og tilrettelegging for forskerne vil etter hvert overtas av Helsedataservice (4). Dette er en ny nasjonal førstelinjetjeneste for tilgang til helsedata til sekundærbruk. Før jul vedtok regjeringen at hoveddelen av Helsedataservice skal legges til Tynset. Planen er at Helsedataservice skal være operativt fra 1. september. Det er et stort arbeid som må gjøres før alt dette er oppe og går.
Internasjonalt samarbeid er viktig for å kunne si noe om effekter av legemiddelbehandling. I dette nummeret beskriver Cohen og medarbeidere hvordan man ved å etablere en «Common Data Model (CDM)» kan forenkle samarbeidet på tvers av land og kontinenter med tanke på analyser av individbaserte data etter samme mal. Med stadig strengere regler for deling av data, blir denne strategien viktig. For veldig sjeldne utfall kan det imidlertid være nødvendig å dele data på individnivå. Det gjenstår å se hvilken betydning Helseanalyseplattformen vil ha for deling av data $\mathrm{i}$ internasjonale prosjekter.

INSPIRE er et prosjekt som skal forenkle tilgangen til data om legemiddelbruk i kreftbehandling. Enerly og medarbeidere beskriver prosjektet, som ble initiert for å hente data om kreftmedisiner elektronisk fra sykehussystemene til Kreftregisteret. Dette gir nye muligheter for farmakoepidemiologiske studier av kreftbehandling.

Klassifikasjonssystemet «Anatomical Therapeutic Chemical (ATC)/Defined Daily Dose (DDD)» utgjør grunnlaget for farmakoepidemiologisk forskning og legemiddelovervåking i Norge og internasjonalt. Avdeling for legemiddelstatistikk ved Folkehelseinstituttet har ansvar for vedlikehold og utvikling av systemet og ivaretar funksjonen som «WHO Collaborating Centre for Drug Statistics Methodology» på oppdrag fra WHOs hovedkontor i Genève. Det kan være utfordrende å bestemme DDD for legemidler der dosene varierer mye, slik som for kreftlegemidler. Olsen og medarbeidere har sammenlignet nylig introduserte DDD for kreftlegemidler med andre måleenheter.

I dette nummeret av Norsk Epidemiologi har vi flere artikler som handler om legemiddelbruk i ulike grupper, der kildene er Reseptregisteret eller selvrapportert legemiddelbruk. Andre artikler fokuserer på farmakoepidemiologisk metode. For eksempel belyser Oteiza og medarbeidere betydningen av analysemetode for å bestemme behandlingsvarighet basert på reseptregisterdata, mens Hagen og medarbeidere drøfter hvordan registerdata kan inngå i effektevalueringer hvor RCT til nå har vært nærmest enerådende.

Flere masterstudenter har fått anledning til å sende inn artikkel basert på sin masteroppgave. Norsk Epidemiologi utgjør en fin publiseringskanal for forskere $\mathrm{i}$ startgropa.

Gjesteredaktørene vil takke for alle fagfellevurderingene. Deres bidrag har løftet artiklene og bedret kvaliteten betydelig. Vi takker Norsk forening for epidemiologi og Norsk forening for farmakoepidemiologi for at de inviterte oss til å være gjesteredaktører. Til slutt, og ikke minst, vil vi rette en hjertelig takk til Trond Peder Flaten for profesjonell redaksjonell ledelse og hyggelig samarbeid. 


\section{REFERANSER}

1. Sommerschild H (red), Legemiddelforbruket i Norge 2015-2019 - Data fra Grossistbasert legemiddelstatistikk og Reseptregisteret / Drug Consumption in Norway 2015-2019 - Data from Norwegian Drug Wholesales Statistics and the Norwegian Prescription Database, Legemiddelstatistikk 2020, Oslo: Folkehelseinstituttet, 2020.

2. Crump C, Sundquist K, Winkleby MA. Transnational research partnerships: leveraging big data to enhance US health. J Epidemiol Community Health 2015; 69: 1029-1030.

3. Helseanalyseplattformen: https://www.ehelse.no/programmer/helsedataprogrammet/helseanalyseplattformen

4. Helsedataservice: https://ehelse.no/aktuelt/etableringen-av-helsedataservice-pa-tynset-er-i-gang

\section{Gjesteredaktørene}

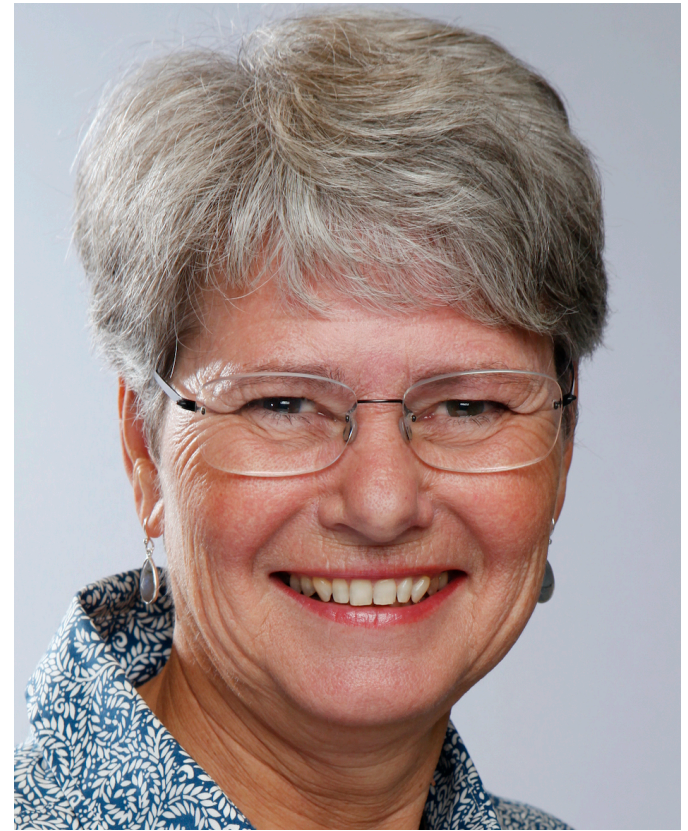

Ingebjørg Buajordet

Statens legemiddelverk ingebjorg.buajordet@legemiddelverket.no

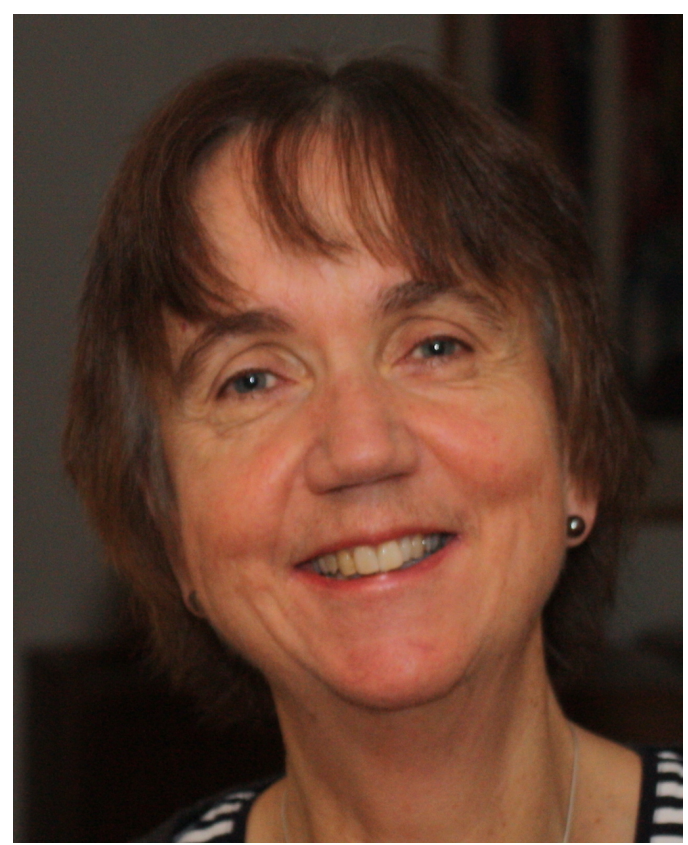

Randi Selmer

Folkehelseinstituttet randi.selmer@fhi.no

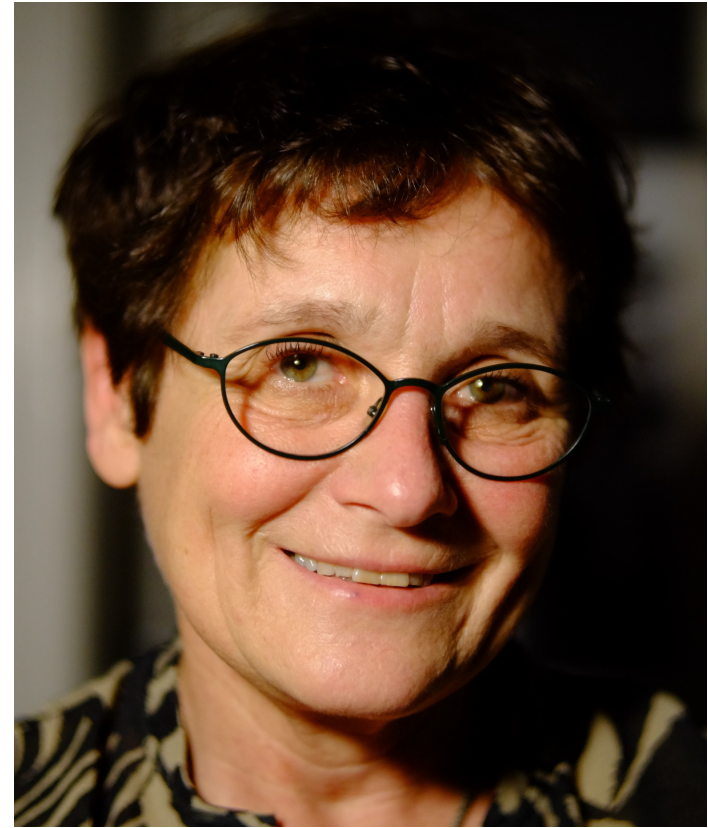

Helle Wallach Kildemoes

Universitetet i Oslo

h.w.kildemoes@farmasi.uio.no, helle.wallach@sund.ku.dk

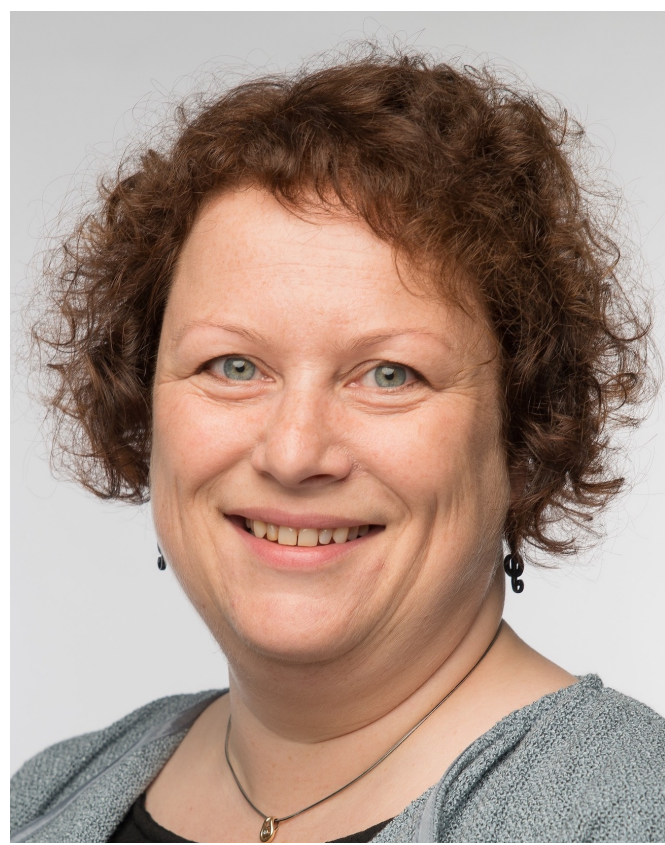

Marit Waaseth

UiT Norges arktiske universitet marit.waaseth@uit.no 